\title{
SOLUSI PERMASALAHAN PENDIDIKAN UNTUK MENCIPTAKAN KEMAJUAN BAGI NEGARA INDONESIA
}

\author{
Muhammad Risalan Uzhma \\ Email: 2010128110004@mhs.ulm.ac.id \\ Program Studi Pendidikan IPS Fakultas Keguruan dan Ilmu Pendidikan \\ Universitas Lambung Mangkurat \\ Banjarmasin
}

\begin{abstract}
Abstrak
Pendidikan adalah kemauan dari orang tua untuk mendukung kemajuan hidup terhadaap anak-anaknya. Dengan adanya pendidikan yang didapat seseorang dari proses pembelajaran, tentunya akan memiliki peranan yang penting terutama untuk kemajuan dalam suatu negara. Dalam pendidikan, tidak akan terlepas dengan permasalahan, permasalahan tersebut yaitu seperti proses berpikir seorang peserta didik yang kurang mampu untuk menyelesaikan suatu permasalahan yang diberikan dalam proses pendidikan, kurang mampunya untuk berdaptasi dan bergaul dengan lingkungan, kecerobohan yang dilakukan oleh pihak instansi atau lembaga pendidikan yang menyebabkan kerugian bagi instansi tersebut, melemahnya moral dan perilaku seorang peserta didik terutama disaat pembelajaran dalam jaringan, dan ketidak merataaan perseberan sarana teknologi. Dari suatu permasalahan juga terdapat sebuah solusi atau pemecahan masalah yang akan memecahkan masalah tersebut.
\end{abstract}

\section{PENDAHULUAN}

Pendidikan adalah aktivitas yang dilakukan oleh individu untuk merubah individu tersebut menuju individu yang lebih baik. Menurut K.H. Dewantara dalam Marwah, Syafe'i, Sumama, (2018: 16), pendidikan adalah kemauan dari orang tua untuk mendukung kemajuan hidup terhadaap anak-anaknya. Dalam pendidikan memiliki keterkaitan dengan pembelajaran, karena pembelajaran merupakan aktivitas yang 
dilaksanakan dalam pendidikan tersebut dengan tujuan untuk menciptakan manusia yang lebih baik. Pembelejaran yang dialami oleh setiap individu terdapat adanya proses yang harus dijalani atau dilakukan untuk tujuan yang ingin dicapai dalam pembelajaran untuk pendidikan. Pendidikan memiliki peran yang sangat penting untuk kemajuan di suatu negara. Dengan adanya pendidikan di suatu negara, negara tersebut dapat mengalami perkembangan untuk menuju kemajuan di negara tersebut.

Dalam pendidikan tidak akan terlepas dengan adanya permasalahan. Tidak hanya dalam pendidikan namun juga yang lainnya, karena dalam hal yang dilakukan pasti ada permasalahan yang dialami dan harus dihadapi. Dalam pendidikan, permasalahan yang terjadi terutama dalam pembelejaran. Permasalahan pendidikan dalam pembelajaran seperti halnya tidak adanya tujuan dalam pembelajaran tersebut, pembelajaran kurang diminati oleh individu yang sedang mengalami proses pembelajaran dan sebagainya.

Dalam era teknologi seperti sekarang, terdapat peran teknologi yang memiliki peran yang penting pada pendidikan. Peran teknologi dalam pendidikan, maka muncul juga inovasi yang tentunya bermanfaat untuk pendidikan. Menurut Pervical dan Henry dalam Syamsuar dan Reflianto (2019: 3), dengan adanya perkembangan teknologi informasi digital yang memanfaatkan teknologi informasi untuk terbentuknya inovasi dalam pembelajaran pada proses pendidikan. Dari hal tersebut juga terdapat permasalahan yang juga menganggu dalam proses pendidikan. Dari sebuah permasalahan, tentu juga terdapat sebuah solusi yang dapat membantu menyelesaikan permasalahan tersebut terutama dalam pendidikan yang memiliki peran penting untuk kemajuan di suatu negara.

\section{METODE PENELITIAN}

Metode yang digunakan dalam penulisan publikasi ilmiah ini dengan metode studi pustaka dengan menelaah serta memahami dari buku-buku, dokumen, atau sumber ilmiah lainnya yang didapatkan google cendekia sebagai sumber utama untuk mendukung dalam penulisan publikasi dari Solusi Permasalahan Pendidikan Untuk Menciptakan Kemajuan Bagi Negara Indonesia. 


\section{PERMASALAHAN PENDIDIKAN}

Dalam setiap aktivitas atau kegiatan yang dilakukan oleh setiap individu pastinya akan menghadapi permasalahan. Permasalahan tersebut akan berdampak kepada individu tersebut seperti dalam pendidikan. Permasalahan yang sering ditemui dalam pendidikan, berkaitan dengan proses berpikir seorang peserta didik yang kurang mampu untuk menyelesaikan suatu permasalahan mengenai pendidikan dalam proses pembelajaran. Berpikir seorang individu dalam proses pendidikan yang masih sulit untuk memecahkan suatu permasalahan yang dihadapi, karena kurangnya pengetahuan maupun pengalaman yang dialami oleh individu tersebut. Dalam lingkungan juga merupakan permasalahan yang sering kali ditemukan dalam pendidikan. Kemampuan individu yang melakukan adaptasi dengan lingkungan sosial menjadi hal yang harus dilakukan oleh seseorang (Syarifuddin, Arisanty, Putro, \& Anis, 2019: 416). Dalam pendidikan, hal tersebut menjadi permasalahan yang mana seorang peserta didik, kurang mampu dalam hal beradaptasi dengan lingkungan sekitarnya, yang tentu saja akan berdampak kepada peserta didik.

Dalam perkembangan teknologi yang tentu saja berdampak kepada pendidikan, seperti halnya dalam sebuah instansi atau lembaga pendidikan yang sangat terbantu dengan adanya teknologi yang semakin berkembang. Akan tetapi, terdapat juga suatu permasalahan walaupun sudah di rancang dengan sebaik mungkin namun tetap ada sebuah celah untuk terjadi permasalahan, yang berasal daru kecerebohan yang dilakukan dalam menjalankan pekerjaan yang dilakukan akan berdampak buruk untuk instansi atau lembaga pendidikan tersebut (Khotimah, Astuti, \& Apriani, 2019: 367).

Permasalahan yang sering terjadi juga dalam pendidikan adalah permasalahan moral dan perilaku seorang peserta didik. Dalam perkembangan teknologi yang semakin pesat dan pada saat sekarang terjadi pandemi COVID-19, yang mengaharuskan peserta didik untuk melaksanakan pembelajaran secara dalam jaringan, yang tentu saja akan berdampak kepada peserta didik tersebut seperti moral dan perilaku. Terdapat perbedaan antara pembelajaran dalam jaringan dengan luar jaringan, yang salah satunya adalah perilaku seorang peserta didik dalam proses menempuh pendidikan, misalkan adanya rasa bermalasan, kurang memperhatikan dan sebagainya dalam proses menempuh pendidikan pada saat sekarang ini. Permasalahan pendidikan selanjutnya 
yang memiliki keterakaitan dengan perkembangan teknologi adalah tidak meratanya sarana teknologi dalam pendidikan, yang biasanya lebih mendominasi di perkotaan dibandingkan di pedesaan, yang tentu saja akan berdampak terhadap pendidikan untuk peserta didik.

\section{SOLUSI PERMASALAHAN PENDIDIKAN}

Permasalahan pendidikan yang merupakan bagian untuk keberhasilan suatu proses pendidikan, harus dihadapi dengan berbagai cara. Cara atau solusi untuk menyelesaikan permasalahan pada pendidikan terkait dengan cara berpikir seorang peserta didik dalam sebuah pembelajaran adalah dengan cara berpikir kritis. Berpikir kritis adalah proses berpikir yang mana seorang individu yaiu peserta didik dituntut untuk berpikir secara tepat untuk mengatasi permasalahan yang di hadapi oleh peserta didik tersebut. Berpikir kritis ini sangat cocok untuk digunakan dalam pembelajaran seperti halnya pada pembelajaran sejarah yang bertujuan untuk memahami peristiwa dan terus mengasah pengetahuan pada pembelajaran sejarah tersebut (Putro, Arisanty, \& Anis, 2020: 68).

Solusi untuk permasalahan dalam pendidikan yang terkait dengan kurang mampunya peserta didik dalam melakukan pergaulan atau beradaptasi dengan lingkungan sekitarnya dengan mengajak peserta didik tersebut untuk berinteraksi dengan lingkungan sekitarnya dengan memberikan pengetahuan bahwa manusia memerlukan lingkungannya untuk menjalani kehidupannya karena individu merupakan makhluk sosial yang memerlukan bantuan dari individu lainnya untuk menjalani kehidupan. Seorang individu dengan lingkungan sekitarnya memiliki keterkaitan yang saling mendukung antara satu dengan yang lainnya. (Mutiani, Noortyani, Tetep, Jumriani, \& Widyanti, 2020: 150). Dengan melakukan pengajakan dan memberikan pemahaman tersebut, peserta didik menyadari begitu pentingnya untuk berinteraksi dan berdaptasi dengan lingkungannya.

Permasalahan pendidikan yang berkaitan dengan teknologi seperti halnya instansi atau lembaga pendidikan yang mempunyai permasalahan karena kecerobohan yang dilakukan dapat diatasi dengan melakukan evaluasi secara berkala untuk tidak terjadinya hal yang serupa. Evaluasi yang dilakukan dengan melihat permasalahan yang 
terjadi dengan didiskusikan dengan bersama untuk tercapainya sebuah penyelesaian untuk hal tersebut. Selain itu, cara yang dapat dilakukan adalah berusaha dengan sebaik mungkin untuk tidak melakukan kecerobohan tersebut dengan berusaha menjauhi ha-hal yang dapat membuat kecerobohan tersebut terjadi kembali.

Solusi untuk permasalahan mengenai melemahnya moral dan perilaku seorang peserta didik dalam proses menempuh pendidikan dengan menggunakan teknologi adalah dengan diadakannya bimbingan dan pertemuan walaupun secara tidak langsung yang terkait dengan moral dan perilaku dari peserta didik yang dilaksanakan dengan konsisten. Dengan adanya bimbingan dan pertemuan, peserta didik diharapkan agar moral dan perilaku mereka menjadi lebih baik lagi walaupun pembelajaran dilakukan dengan dalam jaringan. Dan solusi untuk ketidak merataan sarana teknologi dalam pendidikan yang terjadi di perkotaan dan pedesaan adalah dengan pihak sekolah itu harus mampu untuk menyediakan sarana teknologi baik itu yang didapatkan dari bantuan pemerintah maupun dari pihak sekolah itu sendiri. Dalam pemerintah juga memiliki dana yang terbatas, maka dari itu sekolah harus mampu untuk menyediakan sarana teknologi untuk pendidikan walaupun bantuan dari pemerintah tidak mencukupi.

\section{SIMPULAN}

Pendidikan adalah yang dilakukan oleh individu untuk merubah individu tersebut menuju individu yang lebih baik. Dengan adanya pendidikan di suatu negara, negara tersebut dapat mengalami perkembangan untuk menuju kemajuan di negara tersebut. . Dalam pendidikan memiliki keterkaitan dengan pembelajaran, karena pembelajaran adalah proses yang dilaksanakan dalam pendidikan tersebut dengan tujuan untuk menciptakan manusia yang lebih baik. Dalam pendidikan juga, tidak akan terlepas dengan adanya permasalahan. Permasalahan tersebut seperti proses berpikir seorang peserta didik yang kurang mampu untuk menyelesaikan suatu permasalahan yang diberikan dalam proses pendidikan, kurang mampunya untuk berdaptasi dan bergaul dengan lingkungan, kecerobohan yang dilakukan oleh pihak instansi atau lembaga pendidikan yang menyebabkan kerugian bagi instansi tersebut, melemahnya moral dan 
perilaku seorang peserta didik terutama disaat pembelajaran dalam jaringan, dan ketidak merataaan perseberan sarana teknologi.

Solusi yang diberikan untuk adanya permasalahan adalah untuk permasalahan kurang mampunya peserta didik dalam mengolah proses berpikirnya adalah dengan menanamkan dan menimbulkan proses berpikir kritis. Untuk permasalahan kurang mampunya bergaul dan beradaptasi dengan lingkungan sekitarnya dengan mengajak peserta didik tersebut untuk berinteraksi dan memberikan pengetahuan bahwa individu tidak akan dapat untuk hidup sendiri. Untuk permasalahan kecerobohan yang berdampaka fatal adalah dengan melakukan evaluasi secara berkala dengan tujuan agar tidak terjadi kembali. Untuk permasalahan melemahnya moral dan perilaku peserta didik adalah dengan mengadakan bimbingan dan pertemuan walaupun tidak secara langsung akan tetapi dengan konsisten dalam pelaksanaanya. Dan untuk permasalahan tidak meratanya persebaran sarana teknologi untuk pendidikan adalah dengan tidak terlalu berharap dengan bantuan yang diberikan, akan tetapi dari pihak sekolah khususnya yang bergerak aktif untuk memenuhi sarana teknologi untuk menunjang pendidikan.

\section{REFERENSI}

Akbar, A., \& Noviani, N. (2019, July). Tantangan dan solusi dalam perkembangan teknologi pendidikan di Indonesia. In PROSIDING SEMINAR NASIONAL PROGRAM PASCASARJANA UNIVERSITAS PGRI PALEMBANG.

Arisanty, D., Putro, H. P. N., Normelani, E., Anis, M., \& Arifin, Z. (2018). Socioeconomic impact of Lok Baintan Floating Market as the tourism area for local community. Socio-Economic Impact of Lok Baintan Floating Market as the Tourism Area for Local Community.

Hapijah, H., Putro, H. P. N., \& Hasanah, M. (2020). Tajau Production Activities in Kuin Utara as a Learning Resources on Social Studies. The Innovation of Social Studies Journal, 1(2), 120-128. 
Jumriani, J., Subiyakto, B., \& Syaharuddin, S. (2019). Social Interaction Sasirangan Traders Village in The City of Banjarmasin as a Learning Resources on Social Studies. The Innovation of Social Studies Journal, 1(1), 65-77.

Khotimah, H., Astuti, E. Y., \& Apriani, D. (2019, July). Pendidikan Berbasis Teknologi (Permasalahan dan Tantangan). In PROSIDING SEMINAR NASIONAL PROGRAM PASCASARJANA UNIVERSITAS PGRI PALEMBANG.

Marwah, S. S., Syafe'i, M., \& Sumarna, E. (2018). Relevansi Konsep Pendidikan Menurut Ki Hadjar Dewantara Dengan Pendidikan Islam. TARBAWY: Indonesian Journal of Islamic Education, 5(1), 14-26.

Mutiani, M., Noortyani, R., Tetep, T., Jumriani, J., \& Widyanti, T. (2020). Strengthening Islamic Environmental Awareness through Exploring Poetry as a Learning Resource in Social Studies. Islam Realitas: Journal of Islamic and Social Studies, 6(2), 153-166.

Prasetyo, M. A. M. (2018). Peranan Perilaku Organisasi dan Manajemen Strategi dalam Meningkatkan Produktivitas Output Pendidikan. Idarah (Jurnal Pendidikan Dan Kependidikan), 2(1), 80-101.

Putro, H. P. N., \& Jumriani, J. (2020). KEHIDUPAN SOSIAL DAN EKONOMI MASYARAKAT BANTARAN SUNGAI A SEBAGAI SUMBER BELAJAR IPS.

Putro, H. P. N., Arisanty, D., \& Anis, M. Z. A. (2020, August). Learning Model of History to Wetlands for Historical Consciousness. In International Conference On Social Studies, Globalisation And Technology (ICSSGT 2019) (pp. 67-74). Atlantis Press.

Rahayu, R., Abbas, E. W., \& Jumriani, J. (2021). Social Studies Lesson Planning for Children with Intellectual Disabilities in the Pembina State Special School of South Kalimantan Province. The Kalimantan Social Studies Journal, 2(2), 160169. 
Syamsuar, S., \& Reflianto, R. (2019). Pendidikan dan tantangan pembelajaran berbasis teknologi informasi di era revolusi industri 4.0. E-Tech: Jurnal Ilmiah Teknologi Pendidikan, 6(2).

Syarifuddin, S., Arisanty, D., Putro, H. P. N., \& Anis, M. Z. A. (2019). Kemampuan Adaptasi Masyarakat Transmigran Jawa di Lahan Gambut Desa Jejangkit Timur Kecamatan Jejangkit Kabupaten Barito Kuala. EnviroScienteae, 15(3), 415-419. 